Moh.Yudik Al Faruq
BATIK ANOMART MEDIA ARTS EDUCATION CREATIVITY AND APPRECIATION: CASE STUDY UKM
BATIK ANOMART IN KARTASURA.

\title{
BATIK ANOMART MEDIA ARTS EDUCATION CREATIVITY AND APPRECIATION: CASE STUDY UKM BATIK ANOMART IN KARTASURA.
}

\author{
Moh.Yudik Al Faruq \\ Thesis. Surakarta: Master in Arts Education Program, Faculty of Teacher Training and Education SebelasMaret \\ University Surakarta, November 2016.
}

\begin{abstract}
The purpose of this research is to describe: (1). Knowing Learning Model Is Right And Effective as media education Creativity and art appreciation for the People on UKM Batik Anomart in Kartasura. (2). Knowing what factors that support and hinder the learning process for the Society on UKM Batik Anomart in Kartasura. (3). Knowing the motif form the work produced by the Society through the learning model applied in learning Batik Anomart in Kartasura. The strategy used is rooted single case studies. Data resources used are exploiting informant, place, event, and document. The validity of data was achieved by using resource triangulation and review informant. The technique of data analysis used is interactive analysis. Based on the result of the research, can be concluded that: (1). The learning model is appropriate and effective as educational media creativity and art appreciation for the UKM community in Kartasura Anomart Batik is a method of learning discovery learning. This is because in this model can be investigated methods of model creation process of batik new breakthrough in terms of technique and a different motive to the batik in general. (2). Factors that support the learning process for the People on SMEs Batik AnomartKartasura is their spirit of community appreciation for batik to create a new model, both from a technical point of creation as well as the motive, because therein can be created according to individual wishes of society itself. While the weakness factor is that people still think that batik was an activity that is in the process of creation is very complex and takes a long time, in addition to the community, especially from young people also assume that batik activities are activities that are boring. (3). The form of the motive work produced by the community through learning model applied in learning Batik AnomartKartasura is given that batik is batik, the result of patterns and motifs of Batik Anomart also no restrictions grip particular, tend to be abstract and must always be different, which is the excess of Batik Anomart.
\end{abstract}

Key words: education, creativity, appreciation,UKM Batik Anomart

\section{PRELIMINARY}

Batik originated from Java that is from the word "amba" meaning to write and "point" of the points, so that later became ambatitik-ambatibatik-batik. If viewed in terms of history, batik originated from a common ancestor, known since the seventeenth century. Initially, written and painted on palm leaves. At that time, the motive of batik was dominated by the shape of animals and plants. However, batik had been developed. Ranging from painting motifs of animals and plants, gradually turning the abstract motif that resembles a cloud, temple reliefs, wayang beber, and so forth.

Through merging with art painting style clothes frieze art of batik as we know it today. The type and style of traditional batik as very much. However, patterns and variations in accordance with the philosophy and culture of each region. Indonesia's cultural diversity so rich nation has spawned a variety of styles and types of batik traditional with the characteristic of each daerah. History of batik in Indonesia is closely related to the development of the Majapahit kingdom and thereafter. The development of batik is mostly done in times of Mataram kingdom, then in the kingdom of Solo and Yogyakarta.

Before the birth of batik, batik activities in the beginning everything was done manually, by writing by hand using a media tool called a canting batik, also known as batik. Batik art is an art picture on cloth for clothing that became one of the family culture Indonesian kings of old. Initially, batik was done only in the palace alone. The result was for the king's clothes and family and his followers. Because many of the followers of the king who lived outside the palace, the art of batik was brought by the palace and carried out in their respective places, then this batik art imitated by the people and expanded into women's work to fill his spare time. 
Batik clothing that had only the royal family, then became a popular folk clothing. White fabric that is used when it is the result of homespun. Meanwhile, coloring materials used to make plants native to Indonesia were also made. The plants include noni trees, soga, indigo. For materials made from soda ash soda and salts made from mud.

From the description of the background of the above, the researchers took the title "BATIK ANOMART MEDIA EDUCATION CREATIVITY AND APPRECIATION OF ART: A CASE STUDY UKM BATIK ANOMART Kartasura" because in the application and its creation

has the technical patterns and motifs are unique, even the other from the other, so patterns and motifs have only one world.

Given that batik is batik, then the result of patterns and motifs of Batik Anomart grip was no specific restrictions, tend to be abstract and must always be different, which is the excess of Batik Anomart.

\section{RESEARCH METHODOLOGY}

The location of this research took place in SMEs Batik Anomart, Jl. Bananas No. 52, Kartosuro, Sukoharjo, Central Java.

The research was conducted during two months of the month of November 2016 to February 2016. The first phase of the moon is used for data collection and analysis process including the validation process. While on stage the last month is used to complement the data may still have flaws.

The strategy used in this study is single stuck. Glued research purposes where such research is focused on one goal (one location, or one subject) as its main focus (Sutopo, 2002). Nonetheless portions are fixed studied with regard to the overall context to get the full sense.

According to a statement by Moleong (citing the conclusions Lofland and Lofland, 1984) that the primary source of data in qualitative research is words, and actions, the rest is additional data such as documents and others (2009: 157). The data used in this study are the following definition:

"The informant is a person who is used to provide information about the circumstances of the background research" (Moleong, 2009: 132).
That means that the informants include all parties (people) that help researchers as a source of data for the study. Sutopo (2002) states that "The informant is not just to provide feedback on the requested researcher, but he could have chosen a direction and taste in presenting the information that he has" (p. 50).

In this study, informants involved as sources of data include: Batik SME owners Anomart, namely Wahid Satria, S. Pd. "The place or location associated with the target or the research problem is also one type of data source that can be used by researchers" (Sutopo, 2002: 52).

Places and events are one source of data that isj very important, because in these locations work will be done. Places and events in question are in SMEs Batik Anomart, Jl. Bananas No. 52, Kartosuro. An event is any event that is found in the study site at the time of the study. Of all the events that were found to researchers, will have events related to the research problem that the events relating to the form of batik Anomart, aspects contained in batik Anomart, the functions contained in batik Anomart.

"The document is a written record but also in the form of images or relics related to an activity or event" (Sutopo, 2002: 54). In this study were used as a data source documents include: books on Batik, Batik works Anomart the form of photographs and objects as well as the tools used during the learning process in an effort to educate creativity and appreciation of art in Batik UKM Anomart in Kartasura.

The data collection technique is a step that should be used to conduct a study in order to obtain data in accordance with what is expected. In this research, data collection techniques used to obtain the desired data is as follows:

Observation is an activity of observation of behavior that are relevant to the environment and is available at the sites. It can be associated with the conclusion of the researchers stated, "Observation is used to collect data from any data source in the form of events, places or locations and objects as well as the recording of images" (Sutopo, 2002: 64).

In a study conducted to direct observation (involved), the researchers directly plunge into the destination location to observe the activities of research relevant to the research. The object of observation include: 
a) Description Fields; b) The background of the emergence of UKM Batik Anomart in Kartasura; c) The activities UKM Batik Anomart in Kartasura educational effort of artistic creativity; d) The activities UKM Batik AnomartKartasura the educational effort of art appreciation; e) Discussion.

"The interview is a conversation with a purpose. The conversation was conducted by two parties, the interviewer (interviewer) who ask questions and interviewees (interviewee) that provide answers to questions that "(Moleong, 2009: 186). Shape and type requirements tailored to the needs and circumstances of informants, so that with this interview is expected to obtain the information as needed.

In this study, the interview was used in-depth interviews that led to the depth of information to reveal and to know the data structure but with a strict no question that the more focused and information collected further and deeper. It can be associated with the conclusion of the researchers stated, "The interview in qualitative research is generally not done in a structured tight and closed questions as in quantitative research, but done in an unstructured, or often referred to as in-depth interviews"

(Sutopo, 2002: 59). In-depth interviews of his interview technique is flexible and open, unstructured tight, not in a formal atmosphere and can be repeated on the same informant.

Interviews were conducted to owners UKM Batik Anomart namely Wahid Satriya, S.Pd, in order to obtain data concerning the background of UKM Batik Anomart in Kartasura, as well as the activities UKM Batik AnomartKartasura the educational effort of creativity and art appreciation.

The data available documentation can not be ignored because as documentation material stores a lot of information or data that is meant to complement and extend the data that has been obtained. It can be associated with the conclusion of the researchers stated, "written document and archive the data sources which often has a very important position in qualitative research" (Sutopo, 2002: 69).

In this case the documents used are books about Batik, Batik works Anomart the form of photographs and objects as well as the tools used during the learning process in the educational effort of creativity and art appreciation at UKM Batik Anomart in Kartasura.

The data that was gathered, collected and recorded in research activities should be sought for stability and legitimacy. Because the validity and accuracy of data is something very important in the study. It can be associated with the conclusion of the researchers stated, "The validity of this is a guarantee for the stability of the conclusions and interpretations of meaning as a result of research. In qualitative research, there are several ways that can be selected for the development of the validity of research data "(Sutopo, 2002: 78).

So on that basis, the data need to be tested truth and validity through the following ways:

Regarding the notion of triangulation, Moleong (2009) argues, "Triangulation is a technique that utilizes data validity checking something else. Outside of that data for the purpose of checking or as a comparison to data "(p. 330).

This study used triangulation of sources, comparing the various sources of data obtained in the form of a list of results, informant interviews, observation and analysis of documents or records. This is consistent with the conclusion that Patton, triangulation with the source means to compare and check to return the degree of confidence in the information obtained through time and different tools in qualitative research (Moleong, 2009: 330).

Review informant is a business development validity of the research that is often used by qualitative researchers. An expert study

states: In this study, the data that has been prepared will be shown to the informant to be checked again to maintain its legitimacy.

About the notion of data analysis techniques, Moleong (2009) argues, "data analysis is the process of organizing and sorting data into patterns, categories, and unit basic description so you can find the theme and can be formulated working hypotheses as suggested by the data" (p. 280). The process of data analysis is intended to gain an understanding of the data and draw conclusions from collected data through observation, interviews, and documentation. 
This study uses an interactive model, Sutopo (2002) argues, "In this form researchers still move between the three components of the analysis with the data collection process for data collection activities taking place. After data collection ends, researchers move between the three components of the analysis by using the remaining time for research "(p. 95). In the interactive analysis model, there are three grooves activities occurring simultaneously, namely:

Regarding the definition of data reduction, Matthew B. Miles and A. Michael Huberman (1992) argues, "data reduction is defined as the electoral process, focusing on simplification, abstraction and transformation of raw data that emerged from the notes written in the field" ( $p$. 16).

Data reduction process has been carried out since the decision-making work plan, the selection of cases, preparation of proposals, made a statement as well as a data collection method will do. This continued for data collection lasted until the final report.

Regarding the definition of data presentation, Matthew B. Miles and A. Michael Huberman (1992) argues, "the presentation of data is a set of structured information that gives the possibility of drawing conclusions and taking action" (p. 17).

By looking at the presentation of the research data it will be easier to understand the things that happen and allow us to grind the analysis based on that understanding. Presentation done after the data is collected, then grouped into several sections according to the type of problems, from that obtained at the whole picture, which will facilitate the understanding of things and processes.

This step is the final step in the process of data analysis, which is a step to draw conclusions on the data collected. Since the start of data collection, the researcher must try to catch a variety of things that are important and need to understand the meaning of various terms encountered in order to make accurate conclusions regarding these data.

Withdrawal of the final conclusions need not wait for the data collection ends, the conclusions need to be verified in the form of repetition with fast motion, the activity carried out in the form of interaction with the cyclic process.

Research procedures are stages that must be done by a researcher, where the stages of this study will provide an overview of the overall planning, implementation of data collection, data analysis and interpretation of data collected up to the writing of research reports.

\section{RESEARCH RESULT \\ A. Definition of Batik}

Batik (or word Batik) comes from Javanese "amba" meaning to write and "nitik". The word batik itself points to pattern making techniques using a canting or cap - and dyeing fabric using a pattern color barrier material "night" (wax) applied on the fabric, so resist the entry of the dye. In English, this technique is known as wax-resist dyeing. So batik fabric is a fabric that has a decorative or shades made with canting and cap by using the night as the color barrier material. This technique can only be applied on a material made from natural fibers such as cotton, silk, wool and can not be applied on the fabric with man-made fibers (polyester). Cloth making patterns and coloring are not using this technique known as batik patterned cloth - usually made on an industrial scale with a printing technique (print) - instead of batik cloth.

Batik is one way of making fabrics. Besides batik can refer to two things. The first is a technique of coloring cloth using the night, this technique is one of the ancient art form that is useful for preventing the coloring part of the fabric. In International literature, this technique is known as wax-resist dyeing.Pengertian second is a fabric or clothing made with these techniques, including the use of certain motifs that have specificity. Batik Indonesia, as the overall engineering, technology, and development and related cultural motifs.

Batik is also the sort of craft that has high artistic value and has become part of the culture of Indonesia (especially Java) since long. Javanese women in the past made their skills in batik as livelihood, so in the past, batik work was exclusively women's work. Since the industrialization and globalization, which introduce automation techniques, batik new type emerged, known as the "Cap and Batik Batik Print", which allows the entry of men into this 
field. Exceptions to this phenomenon, namely the coastal batik masculine lines as you can see in shades of "Mega Clouds", which in some coastal areas batik work is common for men. While traditional batik produced by the technique of handwriting using canting and malam is called batik.

Variety style and color Batik influenced by various foreign influences. Initially, batik has a variety of patterns and colors are limited, and some shades should only be used by certain circles. However, coastal batik absorb various external influences, such as foreign traders and also in the end, the invaders. Bright colors like red popularized olehTionghoa, who also popularized the style phoenix. Nation European colonists also took an interest in batik, and the result is a pattern of flowers previously unknown (such as tulips) and also objects brought by the invaders (the building or carriage), as well as favorite colors they like the color blue. Retain traditional batik coraknya, and is still used in traditional ceremonies, because usually each style has a representation of each.

Batik technique has been known for thousands of years ago. No historical information is quite clear about the origins of batik. Some suspect this technique comes from the Sumerian, later developed in Java after brought by Indian traders. Currently batik can be found in many countries such as Indonesia, Malaysia, Thailand, India, Sri Lanka and Iran. Besides Asia, batik is also very popular in some countries on the African continent. However, batik is very famous in the world is a batik from Indonesia, especially from Java. Batik tradition was originally a hereditary tradition, so occasionally a recognizable motif batik originated from a particular family. Some batik may indicate the status of a person. Even today, some tradisional batik motif is only used by the family palace of Yogyakarta and Surakarta.

Batik is the ancestral heritage of Indonesia (Java) that until now still exists. Batik is also first introduced to the world by President Soeharto, who at that time wore batik at the UN Conference. UNESCO appointed Indonesian batik as masterpieces of human cultural heritage on October 2, 2009.

\section{B. Batik in Indonesia}

Variety style and color Batik influenced by various foreign influences. Initially, batik has a variety of patterns and colors are limited, and some shades can only be used by certain circles. However, coastal batik absorb various external influences, such as foreign traders and colonizers. Bright colors like red popularized by the Chinese, who also popularized the style of a traditional phoenix.Batik retaining coraknya, and still used in traditional ceremonies, because usually each style has a representation of each.

Based on the types of Batik technique is as follows: Batik is decorated with fabric textures and patterns by hand. Batik making this type takes approximately 2-3 months. Batik Cap is decorated with fabric textures and patterns created with batik cap (usually made of copper). Batik-making process of this type takes approximately 2-3 days. Batik Painting is the process of making batik with a direct way to paint on a white cloth.

Types of Batik Based Pembuatannya Origin are as follows: Java Batik is an artistic heritage, the people of Indonesia, especially Java controlled by the Javanese from generation to generation. Javanese Batik motifs are different. The difference is common motif motives because it has a meaning, the purpose is not just an image but the meaning that they can from their ancestors, ie adherents of animism, dynamism or Hindu and Buddhist. Javanese Batik Solo developed in many areas or commonly called the Solo batik.

\section{Batik Anomart}

In the application and its creation, Batik Anomart a contemporary batik, batik technique has unique patterns and motifs, and even the other from the other, so have patterns and motifs only one in the world.

Given that batik is batik, then the result of patterns and motifs of Batik Anomart grip was no specific restrictions, tend to be abstract and must always be different, which is the excess of Batik Anomart.

From some of the above explanations, researchers will explain more about batik Anomart as educational media creativity and art appreciation. 


\section{How to Make Batik Anomart}

a) Tools and materials must be prepared as follows:

Here are the tools and materials must be prepared to make Batik Anomart: Fabrics mori (can be made of silk or cotton), Canting as a means of forming a motive, Brush, gawangan (place for draped fabrics), Candle (night) was disbursed, Frying Pan and small stove to heat the wax, Pots and great for nglorod stove, mixer, immersion tubs, water, gloves, pencil, pattern, Caustic soda, dye solution.

b) step of making batik anomart:

Mewolsum edges of the fabric, Drawing motif (molani), Process mencanting namely paint (wax) night using a canting (caged / dicantangi) by following the pattern, Poses Staining Stage One, Process Pencantingan second phase (nembok), Once dry, re-doing process namely batik painting with wax using canting / brush to cover / brickwork parts to be maintained at the first coloring, tinting process Second Stage, next process is nglorot, where the fabric has been colored boiled boiling water mixed with soda caustik. The aim is to remove the layer of wax, so the motif that has been previously drawn clearly visible.

The steps are to boil water in a saucepan, then wait for 15 minutes until boiling, after boiling water and then fill in caustic soda batik cloth that has been through the process of coloring the second phase was put into a pot of boiling water. Batik cloth then it circled by using a stirrer (large ladle). Candles stuck in the batik cloth do not disappear easily, but there are still some candles still stuck in batik cloth. After stirred into boiling water mixed caustic soda for 15 minutes, then the batik cloth in the lift and put into a large bucket containing clean water, then continue with a diminished-sagged and rubbed the rest of the wax still attached earlier. After that, the next process is to continue boiling water for a second time to eliminate the remnants of wax still stuck in the batik cloth. After the water boils enter caustic soda, then batik cloth in the insert and begin to sag-sagged approximately 15 minutes. After that batik cloth is taken, then rinse with clean water. After all the wax is gone and the former canting batik cloth is clean, then the batik cloth is in the sun in the shade and not exposed to direct sunlight so that the color does not fade.
Once it is dry the batik cloth, batik cloth can be raised and ready for use.

\section{E. Efforts Batik Anomart in Media Education Creativity and Art Appreciation.}

The word comes from the Latin media and is the plural of the word medium, which literally means an intermediary or introduction. Media is an intermediary or an introductory message from the sender to the recipient of the message (Sadiman, Rahardjo, et al. 1993).

Use of media education (education) creativity and art appreciation are on Batik Anomart, by way of procurement workshop, that is by making batik with steps and techniques that are found to be difficult in terms of creation, even the motive no grip certain rules and seem abstract, so Anomart motif is unique and the only one in the world.

From the above understanding, it can be concluded that media education (education) is a medium of learning, and understanding of the learning media is a means of education that can be used as an intermediary in the process of learning to enhance the effectiveness and efficiency in achieving the objectives of teaching.

\section{CONCLUSIONS AND SUGGESTIONS}

Batik originated from Java that is from the word "amba" meaning to write and "point" of the points, so that later became ambatitik-ambatibatik-batik. If viewed in terms of history, batik originated from a common ancestor, known since the seventeenth century. Through merging with art painting style clothes frieze art of batik as we know it today. The type and style of traditional batik as very much. However, patterns and variations in accordance with the philosophy and culture of each nation daerah.Ragam Indonesian culture is so rich and has spawned a variety of styles and types of batik traditional with the characteristics of each region. in the application of engineering and its creation has unique patterns and motifs, and even the other from the other, so have patterns and motifs only one in the world. Given that Anomart batik is batik, then the result of patterns and motifs of Batik Anomart grip was no specific restrictions, tend to be abstract and must always be different, which is the excess of Batik Anomart. 


\section{Moh.Yudik Al Faruq}

BATIK ANOMART MEDIA ARTS EDUCATION CREATIVITY AND APPRECIATION: CASE STUDY UKM BATIK ANOMART IN KARTASURA.

The need for planting a greater understanding to the public that in terms of making batik, especially batik Anomart actually very easy, it is this which makes the Batik Anomart should be more active in preaching the ideals and intentions and objectives in making batik. Perhaps by way of using the power of social media goals and objectives will be achieved faster.

\section{BIBLIOGRAPHY}

Aliya, 2010.Batik Pekalongan.JakartaTimur : CV. Rama Edukasi Utama

Hindayani, Fisika, 2009. Mengenal dan Membuat Batik.Jakarta Selatan : Buana Cipta Pustaka

Miles, Matthew B. dan Huberman, A. Michael.(1992). Analisis Data Kualitatif. Terj.Tjetjep Rohendi Rohidi. Jakarta: UI Press.

Moleong, Lexy J. (2001).Metodologi Penelitian Kualitatif. Bandung: Remaja Rosdakarya.

Sutopo, H.B. (2002). Metodologi Penelitian Kualitatif: Dasar teori dan terapannya dalam Penelitian. Surakarta :Sebelas Maret University Press. 